\title{
Partial characterisation of dimethylsulfonio- propionate (DMSP) lyase isozymes in 6 strains of Emiliania huxleyi
}

\author{
Michael Steinke ${ }^{1, *}$, Gordon V. Wolfe ${ }^{2}$, Gunter O. Kirst ${ }^{1}$ \\ ${ }^{1}$ Marine Botany, University of Bremen FB2, D-28334 Bremen, Germany \\ ${ }^{2}$ College of Oceanic and Atmospheric Sciences, Oregon State University, Corvallis, Oregon 97331-5503, USA
}

\begin{abstract}
We characterised and compared dimethylsulfoniopropionate (DMSP) lyase isozymes in crude extracts of 6 axenic Emiliania huxleyi cultures (CCMP 370, 373, 374, 379, 1516, and strain L). This enzyme cleaves DMSP to form dimethyl sulfide (DMS), acrylate and a proton, but the function of this reaction in algae is still poorly understood. Most of the cultures produced high concentrations of intracellular DMSP, which was constant over the growth cycle and ranged from 157 to $242 \mathrm{mM}$, except for 1516 which had 50 mM DMSP cell ${ }^{\top}$ Extracts of all strains produced DMS from exogenous DMSP in vitro. DMSP lyases appeared constitutive, but enzyme activity and behaviour varied greatly among strains, and did not correlate with intracellular DMSP concentration. Strains 373 and 379 showed high DMSP lyase activities (12.5 and 6.1 fmol DMS cell ${ }^{-1} \mathrm{~min}^{-1}$, respectively), whereas DMS production was more than 100-fold lower in 370,374, 1516 and $\mathrm{L}$. This difference was intrinsic and the general pattern of high-and low-activity strains remained true over more than a 1 yr cultivation period. The cleavage reaction was optimal at $\mathrm{pH} 6$ in the strains with high lyase activity and $\mathrm{pH} 5$ was optimal for 374,1516 and L. Strain 370 showed increasing activity with increasing $\mathrm{pH}$. Experiments with additions of 0.125 to $2 \mathrm{M} \mathrm{NaCl}$ indicated halotolerant DMSP lyases in 373,379 and 374 . However, the halophilic DMSP lyases in 370 and L required $1 \mathrm{M} \mathrm{NaCl}$ addition for optimal DMSP cleavage, and 1516 showed optimal activity at $2 \mathrm{M} \mathrm{NaCl}$. These results suggest that there are several structurally different DMSP lyase isozymes within E. huxleyi. However, it cannot be ruled out that varying concentrations of DMSP lyase per cell may have contributed to the differences in enzyme activity per cell. Comparison with other algal taxa indicates several families of DMSP lyases, hinting at possibly different cellular locations and functions, and varying DMS production under natural conditions.
\end{abstract}

KEY WORDS: Dimethylsulfoniopropionate (DMSP) lyase - Isozymes · Dimethyl sulfide (DMS) · Marine sulfur cycle Biogeochemistry. Emiliania huxleyi

\section{INTRODUCTION}

Some marine micro- and macroalgae synthesise the sulfur compound dimethylsulfoniopropionate (DMSP), which is accumulated to high intracellular concentrations ( $\mathrm{mM}$ to $\mathrm{M}$ ) in some algal taxa (Ulvophyceae, Haptophyceae, Dinophyceae) (Reed 1983, Keller et al. 1989, Blunden et al. 1992). DMSP is probably the most important precursor for volatile dimethyl sulfide

- Present address: School of Environmental Sciences, University of East Anglia, Norwich NR4 7TJ, United Kingdom.

E-mail:m.steinke@uea.ac.uk
(DMS), the major source of biogenic sulfur in the marine atmosphere (Andreae \& Jaeschke 1992, Liss et al. 1997). DMS is important for atmospheric chemistry (Andreae et al. 1985, Plane 1989), and may affect the formation of cloud-condensation nuclei, hence influencing global climate (Bates et al. 1987, Charlson et al. 1987, Malin et al. 1992). Therefore, the production of DMSP and the microbial pathways resulting in DMS have received much attention recently (see Kiene et al. 1996, review by Malin \& Kirst 1997).

Abiotic decomposition of DMSP to DMS, acrylate and a proton is slow in natural seawater (Dacey \& Blough 1987), therefore cleavage via the enzyme DMSP lyase 
salinity of 30 practical salinity units (psu) with distilled water. Light was supplied by fluorescent tubes at $40 \mu \mathrm{mol}$ photons $\mathrm{m}^{-2} \mathrm{~s}^{-1}$ under a light-dark rhythm of 18:6 h. Culture and experimental temperatures were $15^{\circ} \mathrm{C}$.

Growth experiments. Strains were transferred from stock cultures into 1 l square polycarbonate bottles (Nalgene) to reach initial cell densities of 3000 cells $\mathrm{ml}^{-1}$. At a light intensity of $80 \mu \mathrm{mol}$ photons $\mathrm{m}^{-2} \mathrm{~s}^{-1}$ and a light-dark rhythm of $18: 6 \mathrm{~h}$, cell number, particulate DMSP and chlorophyll a were monitored daily at noon over a growth period of 2 wk. Before taking a subsample for the measurements, bottles were gently inverted by hand to distribute cells. Specific growth rates were calculated using cell counts (see below) during logarithmic growth.

Cell size measurements. Light microscopy was used to estimate the cell size of living cells in mid-logarithmic growth. Using an eyepiece micrometer, which was calibrated with a stage micrometer at 1000 -fold magnification, 15 to 20 cells were measured to the nearest $0.5 \mu \mathrm{m}$. The values were averaged and 1 standard deviation was calculated.

Cell enumerations and examinations for bacterial contamination. Depending on cell density, 0.25 to $5 \mathrm{ml}$ of culture was preserved and stained with acridine orange (Sherr et al. 1993) before filtering onto 0.2 or $0.8 \mu \mathrm{m}$ black stained polycarbonate filters (Poretics, diameter $25 \mathrm{~mm}$ ). Cells were enumerated by counting 20 squared grids at 400 -fold magnification (equivalent to a filter area of $0.24 \times 0.24 \mathrm{~mm}$ ) using an epifluorescence microscope (Nikon Diaphot, blue excitation). Cell numbers in the individual grids were averaged and the number of cells per $\mathrm{ml}$ of cell culture was calculated. Additionally, the same staining method was used to inspect the cultures for bacterial contamination (Hobbie et al. 1977). At 1000-fold magnification, at least 20 fields of vision were examined for bacterial cells. Also, cell suspensions were plated onto $1 \%$ peptone-seawater-agar and incubated for several days in the dark. Bacterial contamination was not detected with either method.

Chlorophyll a measurements. On every sampling day, an aliquot of cell culture $(10 \mathrm{ml})$ was filtered with a low vacuum (less than $100 \mathrm{~mm} \mathrm{Hg}$ ) onto a glass fibre filter (Whatman GF/F), which was then individually wrapped in aluminium foil and stored at $-20^{\circ} \mathrm{C}$ prior to analysis. Chl a was extracted for $24 \mathrm{~h}$ at $4^{\circ} \mathrm{C}$ in the dark using $6 \mathrm{ml} 90 \%$ acetone and measured with a fluorometer (Kleinfeld TCF) which was calibrated with 20 to 200 ng chl a. Values for chl a cell-1 during logarithmic growth were averaged and 1 standard deviation was calculated.

Particulate DMSP measurements. Duplicate samples of cell culture $(10$ or $20 \mathrm{ml})$ were filtered with a low vacuum (less than $100 \mathrm{~mm} \mathrm{Hg}$ ) onto Whatman $\mathrm{GF} / \mathrm{F}$ filters which were directly transferred into glass vials ( $25 \mathrm{ml}$ volume). Ice-cold $10 \mathrm{M} \mathrm{NaOH}(5 \mathrm{ml}$ ) was added before closing the vials gas-tight with a tefloncoated silicone septum and a screw cap. During a $24 \mathrm{~h}$ dark incubation the DMSP completely hydrolyses to DMS, acrylate and $\mathrm{H}_{2} \mathrm{O}$ (Challenger 1959). An aliquot (50 to $250 \mu l$ ) of the gas phase was taken with a gastight syringe and injected into a gas chromatograph (Shimadzu GC-9A) equipped with a flame photometric detector and a column packed with Chromosorb 101 (Macherey-Nagel). At a column temperature of $190^{\circ} \mathrm{C}$ and a carrier gas flow of $60 \mathrm{ml} \mathrm{min}{ }^{-1}$ nitrogen, DMS eluted at $0.9 \mathrm{~min}$. Peak areas were quantified relative to DMSP standards of 0.12 to $12 \mu \mathrm{M}$ in $10 \mathrm{M} \mathrm{NaOH}$. Other analytical details were the same as those reported by Steinke \& Kirst (1996). The results from the duplicate measurements were averaged and particulate DMSP per cell and internal DMSP concentration calculated for every sampling day. The values during logarithmic growth were then averaged and 1 standard deviation was calculated.

DMSP lyase activity measurements. Emiliania huxleyi cell culture in late exponential growth (1 1) was concentrated to $50 \mathrm{ml}$ by centrifugation for $20 \mathrm{~min}$ at $3500 \times g$ and $15^{\circ} \mathrm{C}$. After a second centrifugation for $10 \mathrm{~min}$ at $20000 \times g$ and $4^{\circ} \mathrm{C}$, the resulting pellet was resuspended in $3 \mathrm{ml}$ buffer containing $160 \mathrm{mM}$ citric acid/phosphate pH 6, with $500 \mathrm{mM} \mathrm{NaCl}, 20 \mathrm{mM}$ $\mathrm{CaCl}_{2}, 1 \mathrm{mM}$ dithiothreitol (DTT) and a protease inhibitor cocktail (Complete Cocktail, Boehringer, 1 tablet $50 \mathrm{ml}^{-1}$ ). Cells were homogenised on ice using ultrasound (2 times $5 \mathrm{~s}$; Branson Sonifier Cell Disruptor B-15). DMSP lyase activity was stable in frozen crude extracts so that $500 \mu \mathrm{l}$ aliquots were stored at $-20^{\circ} \mathrm{C}$ until activity measurements were conducted.

Prior to all enzyme experiments, the crude extracts of 373 and 379 were diluted $1: 100$ and $1: 10$, respectively, with the test buffer used in the assay. DMSP lyase activity measurements were performed in duplicates (if not stated otherwise) in $1.8 \mathrm{ml}$ glass vials capped with teflon-coated silicone septae. After mixing $245 \mu \mathrm{l}$ of test buffer with $50 \mu \mathrm{l}$ crude extract, we monitored the possible outgassing of DMS from the extracts for $10 \mathrm{~min}$. Thereafter, the enzymatic reaction was started by the addition of $5 \mu 11.2 \mathrm{M}$ DMSP (final concentration $20 \mathrm{mM}$ ). Depending on DMSP lyase activity the DMSP cleavage was followed for 10 to $120 \mathrm{~min}$ at $30^{\circ} \mathrm{C}$. A heated control $\left(45 \mathrm{~min}\right.$ at $90^{\circ} \mathrm{C}$ proved to be sufficient) was used to quantify abiotic DMS production. Rates of DMS production were calculated and duplicate measurements averaged.

$\mathrm{NaCl}$ and $\mathrm{pH}$ requirements of DMSP lyase. To determine the $\mathrm{NaCl}$ requirements of DMSP lyase, a buffer with $160 \mathrm{mM}$ citric acid/phosphate pH 6 con- 
taining $1 \mathrm{mM}$ DTT and protease inhibitor cocktail was adjusted to 0 to $2 \mathrm{M} \mathrm{NaCl}$ using a $5 \mathrm{M} \mathrm{NaCl}$ stock solution in citric acid/phosphate buffer. After $\mathrm{NaCl}$ additions, the test buffer was titrated to $\mathrm{pH} 6$ using $1 \mathrm{M} \mathrm{HCl}$.

The effect of $\mathrm{pH}$ on DMSP lyase activity was investigated with a series of citric acid/phosphate buffer at $\mathrm{pH} 2,3,4,5,6,7$, and 8 (no duplicate measurements). $500 \mathrm{mM} \mathrm{NaCl}$ was added to this buffer to allow for measurements with Emiliania huxleyi strains requiring $\mathrm{NaCl}$ for DMSP lyase activity. After each experiment the $\mathrm{pH}$ was checked to exclude possible $\mathrm{pH}$ changes during the measurements.

Synthesis of DMSP chloride. Dimethyl sulfide (100 ml, Riedel-de Haen), $100 \mathrm{ml}$ acrylic acid (Merck) and $100 \mathrm{ml}$ benzaldehyde (Merck), all analysis grade, were mixed on ice in a round-bottomed flask and bubbled for $10 \mathrm{~min}$ with hydrochloric acid vapour. The DMSP chloride (DMSP-Cl) which precipitated was harvested on a glass frit and rinsed with $50 \mathrm{ml}$ of benzaldehyde. After freeze-drying the DMSP-Cl for $24 \mathrm{~h}$, it was dissolved in boiling ethanol and re-crystallised by slow cooling to $-20^{\circ} \mathrm{C}$. This procedure was repeated a second time before the DMSP.Cl was analysed for purity by NMR-spectroscopy. Commercially prepared DMSP-Cl (Research Plus Inc., New Jersey, USA) was used as a standard.

\section{RESULTS}

\section{Growth experiments}

Cell numbers and particulate DMSP increased exponentially for at least $5 \mathrm{~d}$ in all strains as observed previously (Wolfe \& Steinke 1996). Specific growth rate $(\mu)$ varied from 0.62 to $0.82 \mathrm{~d}^{-1}$, resulting in final cell densities of $3.5 \times 10^{5}$ to $7 \times 10^{5}$ cells $\mathrm{ml}^{-1}$ (Table 2 ). On a per cell basis, the DMSP concentration was lowest in 1516 (3.6 fmol DMSP cell ${ }^{-1}$ ) and averaged $10.8 \mathrm{fmol}$ DMSP cell ${ }^{-1}$ in $370,374,379$ and strain L. The highest DMSP concentrations were observed in $373(18.9 \mathrm{fmol}$ DMSP cell ${ }^{-1}$ ) (Table 2).

Cell diameters in living cells ranged from 4.4 to $5.3 \mu \mathrm{m}$ as observed with a light microscope, resulting in calculated cell volumes (assuming spherical cells) of 44 to $78 \times 10^{-12} \mathrm{~cm}^{3}$ (Table 2). Therefore, intracellular DMSP concentrations are low in 1516 (50 $\mathrm{mM}$ ), higher in strain $\mathrm{L}(157 \mathrm{mM}$ ) and average $219 \mathrm{mM}$ in the other strains (Table 2). These values were higher than previously reported for 370 and 373 (113 and $107 \mathrm{mM}$, respectively) (Wolfe \& Steinke 1996). Different culture conditions (different batches of natural seawater, light quality and quantity, light-dark cycles of $18: 6 \mathrm{vs} 16: 8 \mathrm{~h}$, reduced iron concentration in $f / 2$ medium) may have resulted in different physiological responses with

Table 2. Emiliania huxleyi. Comparison of growth, cell, chl a and DMSP characteristics for 6 strains

\begin{tabular}{|c|c|c|c|c|c|c|}
\hline \multirow{2}{*}{ Parameter } & \multicolumn{6}{|c|}{ Emiliania huxleyi strain } \\
\hline & 370 & 373 & 374 & 379 & 1516 & L \\
\hline Specific growth rate $\left(\mu, \mathrm{d}^{-1}\right)$ & 0.80 & 0.72 & 0.82 & 0.67 & 0.62 & 0.82 \\
\hline Final cell density $\left(10^{5} \text { cells } \mathrm{ml}^{-1}\right)^{\mathrm{d}}$ & 6.1 & 4.2 & 3.5 & 6.9 & 6.8 & 7.0 \\
\hline \multicolumn{7}{|l|}{ Cell diameter $(\mu \mathrm{m})^{b}$} \\
\hline Arithmetic mean & $4.4(2-5)$ & $5.3(4-8)$ & $49(4-8)$ & $4.8(3-5)$ & $5.2(4-10)$ & 4.7 \\
\hline Standard deviation & 0.5 & 0.5 & 0.4 & 0.6 & 1.0 & 0.6 \\
\hline $\mathrm{n}$ & 20 & 15 & 20 & 20 & 20 & 20 \\
\hline \multicolumn{7}{|l|}{ Cell volume $\left(10^{-12} \mathrm{~cm}^{3}\right)$} \\
\hline Arithmetic mean & 44 & 78 & 62 & 58 & 73 & 55 \\
\hline Standard deviation & 14 & 22 & 15 & 25 & 60 & 26 \\
\hline $\mathrm{n}$ & 20 & 15 & 20 & 20 & 20 & 20 \\
\hline \multicolumn{7}{|l|}{ Chlorophyl] a (pg cell ') } \\
\hline Arithmetic mean & 0.16 & 0.24 & 0.20 & 0.19 & 0.08 & 0.14 \\
\hline Standard deviation. & 0.03 & 0.06 & 0.04 & 0.06 & 0.02 & 0.03 \\
\hline $\mathrm{n}$ & 6 & 5 & 5 & 6 & 6 & 6 \\
\hline \multicolumn{7}{|l|}{ DMSP (fmol cell ${ }^{-1}$ ) } \\
\hline Arithmetic mean & 10.2 & 18.9 & 13.1 & 11.2 & 3.6 & 8.7 \\
\hline Standard deviation & 2.9 & 5.3 & 3.0 & 2.0 & 1.3 & 1.7 \\
\hline n & 8 & 8 & 8 & 9 & 8 & 8 \\
\hline \multicolumn{7}{|c|}{ Intracellular DMSP concentration (mM) } \\
\hline Arithmetic mean & 232 & 242 & 211 & 192 & 50 & 157 \\
\hline Standard deviation & 65 & 67 & 49 & 35 & 1.8 & 31 \\
\hline $\mathrm{n}$ & 8 & 8 & 8 & 9 & 8 & 8 \\
\hline
\end{tabular}


higher cellular DMSP concentrations. However, it may be possible that calibration variance between sulfur measurements in our 2 laboratories could have contributed to the difference. Chl a values ranged from 0.08 to $0.24 \mathrm{pg} \mathrm{cell}{ }^{-1}$ (Table 2), which is similar to values reported previously for Emiliania huxleyi (Pond \& Harris 1996)

\section{DMSP Iyase activities}

We previously showed that DMSP lyase activity per cell is constant over the growth cycle in 370 and 373 (Wolfe \& Steinke 1996). Therefore, it can be assumed that growth stage does not affect DMSP lyase activity per cell in Emiliania huxleyi, and that DMSP lyase activities reported in the present study reflect cell activities independent of cell growth stage.

Activity of DMSP lyase showed high strain-specific variability. At $30^{\circ} \mathrm{C}, \mathrm{pH} 6$ and optimal additions of $\mathrm{NaCl}$ for each strain, DMSP cleavage varied over more than 3 orders of magnitude from 0.002 to $12.5 \mathrm{fmol}$ DMS cell ${ }^{-1} \mathrm{~min}^{-1}$ (Fig. 1).

In 374 , DMS production rate was very low but 370 , 1516 and strain $L$ showed a higher DMS production of 0.01 to $0.03 \mathrm{fmol}^{\mathrm{DMS}} \mathrm{cell}^{-1} \mathrm{~min}^{-1}$ (Fig. 1). Compared to these production rates, in 373 and 379 DMSP lyase activities were more than 100-fold higher 6.1 to $12.5 \mathrm{fmol}^{\mathrm{DMS}}$ cell ${ }^{-1} \mathrm{~min}^{-1}$ ).

Intracellular DMSP concentration did not directly correlate with DMSP lyase activity in investigated

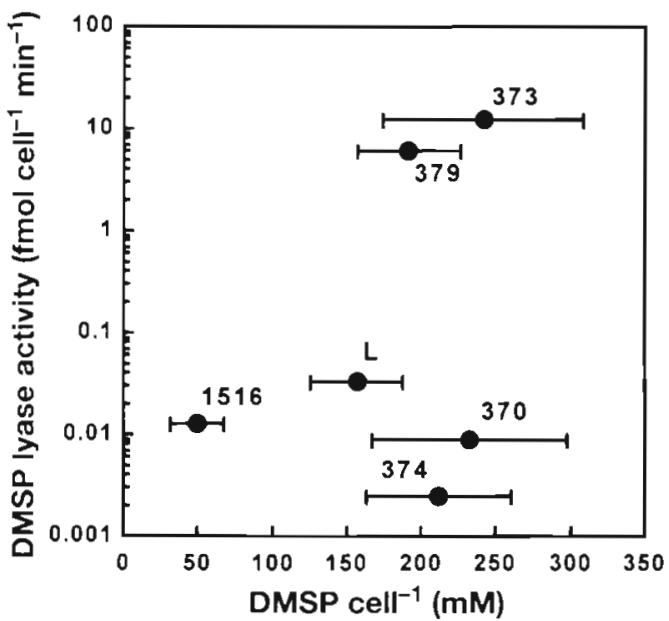

Fig. 1. Emiliania huxleyi. In vitro DMSP lyase activities versus intracellular DMSP concentrations in 6 strains. DMSP lyase activities are for $\mathrm{pH} 6$ and optimal $\mathrm{NaCl}$ concentration as follows: O M (374); $0.25 \mathrm{M}(373) ; 0.5 \mathrm{M}(379) ; 1 \mathrm{M}(370, \mathrm{~L}) ; 2 \mathrm{M}$ (1516). Data shown represent average values. Error bars indicate standard deviation ( $x$-axis, see Table 2 ). The range of data on the $y$-axis $(n=2)$ is smaller than the indicated data points strains. Although DMSP concentrations were very similar in 4 strains $(370,373,374,379), 370$ and 374 showed low DMSP lyase activity, whereas in 373 and 379 the activity was high.

\section{Effect of $\mathrm{NaCl}$ additions on DMSP lyase activities}

Additions of $\mathrm{NaCl}$ resulted in increased DMSP lyase activities in 370, 1516 and strain L (Fig. 2B), whereas 373 and 374 showed reduced DMS production with increasing $\mathrm{NaCl}$ concentrations (Fig. 2A).

Strains $L$ and 370 had maximum activity with $1 \mathrm{M}$ $\mathrm{NaCl}$ added but in 1516 DMSP lyase activity increased up to $2 \mathrm{M} \mathrm{NaCl}$. In contrast to these findings, $\mathrm{NaCl}$ additions to 373 and 374 inhibited lyase activity to 57 and $64 \%$ of optimal activity, respectively. Strain 379 was relatively insensitive to $\mathrm{NaCl}$ additions but activity was slightly increased with 0.5 to $1 \mathrm{M} \mathrm{NaCl}$ added (no measurement at $2 \mathrm{M}$ $\mathrm{NaCl}$.

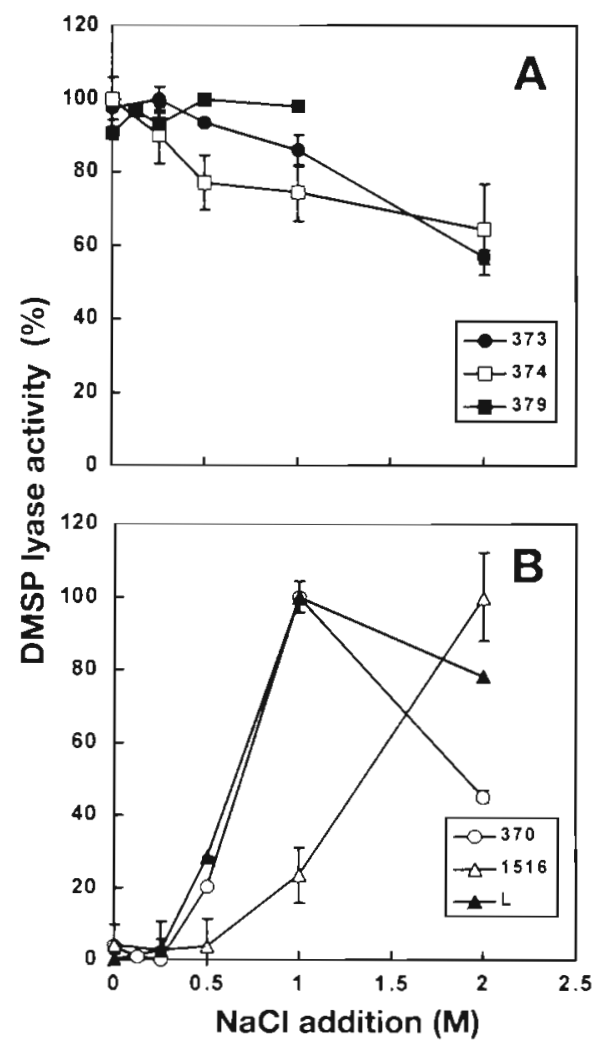

Fig. 2. Emiliania huxleyi. DMSP lyase activities in 6 strains with various additions of $\mathrm{NaCl}$. Maximum DMSP lyase activities $(100 \%)$ of individual strains are as presented in Fig 1 (A) Strains with halotolerant DMSP lyases $(373,374$ and 379$)$. (B) Strains with halophilic DMSP lyases $(370,1516$ and L). Data shown represent average values. Error bars indicate range of data $(n=2)$ 


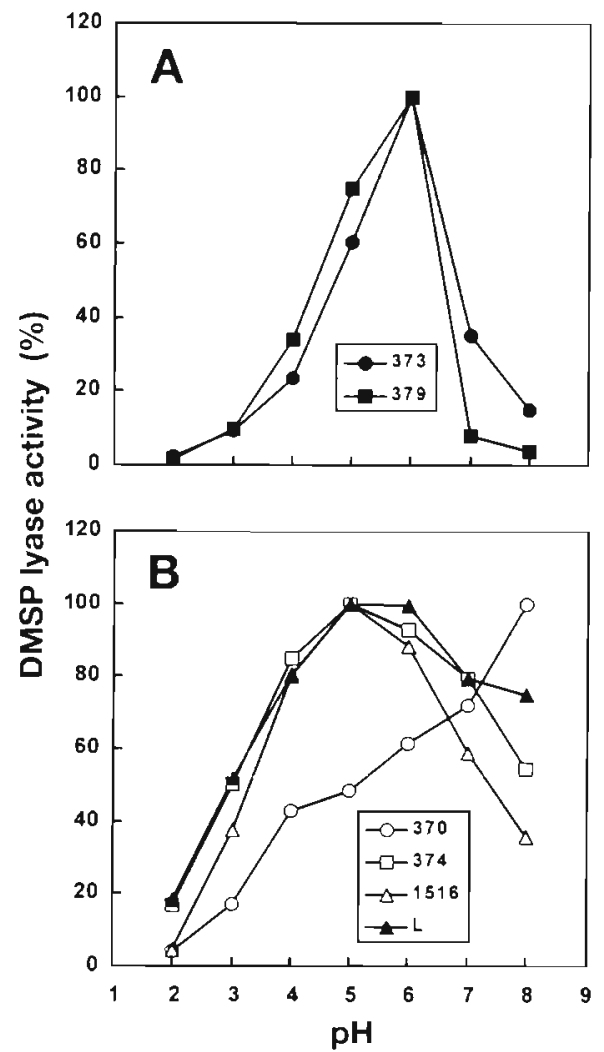

Fig. 3. Emiliania huxleyi. DMSP lyase activities in 6 strains at various $\mathrm{pH}$ levels in citric acid/phosphate buffer, at optimal $\mathrm{NaCl}$ concentration as given for Fig. 1. (A) Strains with high DMSP lyase activities (373 and 379). (B) Strains with low DMSP lyase activities $(370,374,1516$ and $L)$

\section{pH optima}

Various $\mathrm{pH}$ levels revealed further intraspecific differences in DMSP lyase activities. The 2 strains with high lyase activity (373 and 379) had a narrow $\mathrm{pH}$ optimum around $\mathrm{pH} 6$ (Fig. 3A). In contrast, the low activity strains either had a $\mathrm{pH}$ optimum around $\mathrm{pH} 5$ with substantial activity (above $80 \%$ of maximum) at $\mathrm{pH} 4$ and $\mathrm{pH} 6(374,1516$ and L) (Fig. 3B) or showed increasing activity with increasing $\mathrm{pH}$ (370), similar to the DMSP lyase from Phaeocystis sp. (Stefels \& Dijkhuizen 1996).

\section{DISCUSSION}

There have been few isozyme studies in marine phytoplankton taxa, although several authors have compared total cell protein patterns (electrophoretic banding) within a phytoplankton species (Gallagher 1982, Beam \& Himes 1987). The work presented here provides information about intraspecific DMSP lyase variation in Emiliania huxleyi. On the basis of our results we suggest hypotheses concerning the relationship between DMSP lyases in E. huxleyi and enzymes with the same function in other taxa, the conditions under which DMS production might occur, and possible functions of the DMSP cleavage reaction.

\section{Intraspecific DMSP lyase variation}

The Emiliania huxleyi strains exhibited much more variability in DMSP lyase activity than in intracellular DMSP concentration, and there was no correlation between the two. Based on in vitro activity and $\mathrm{pH}$ and $\mathrm{NaCl}$ optima, the DMSP lyase isozymes studied appear to fall into at least 2 groups. Strains 373 and 379 had high activities, roughly 100 -fold per cell higher than the other strains (Fig. 1), exhibited sharp pH optima at 6 with less than $40 \%$ of maximal activity at $\mathrm{pH} 4$ and 7 (Fig. 3A), and showed no $\mathrm{NaCl}$ requirement but inhibition with addition of more than $500 \mathrm{mM} \mathrm{NaCl}$ (Fig. 2A). These 2 strains were isolated from widely separated geographic regions (Sargasso Sea and English Channel, respectively) (Table 1) and also showed phenotypic variation such as cell size (Table 2) and lipid composition (Wolfe unpubl. data).

The other strains had much lower DMSP lyase activities (Fig. 1) but showed marked differences in requirements for in vitro enzyme activity. Strains 370, L and 1516 required high $\mathrm{NaCl}$ concentrations for optimal activity (Fig. 2B), while strain 374 showed no $\mathrm{NaCl}$ requirement but 20 to $30 \%$ inhibition at $\mathrm{NaCl}$ concentrations above $250 \mathrm{mM}$. Strains 374, L and 1516 showed broad pH maxima at 5 and retained about $50 \%$ DMSP lyase activity over pH 3 to 8 (Fig. 3B), while strain 370 showed increasing activity with increasing $\mathrm{pH}$. Therefore, the assay conditions used to generate the data shown in Fig. 1 ( $\mathrm{pH} 6$, optimal $\mathrm{NaCl}$ concentration) result in an underestimation of the DMSP lyase activity in $370\left(0.009\right.$ fmol DMS cell ${ }^{-1}$ $\left.\mathrm{min}^{-1}\right)$. During the $\mathrm{pH}$ experiments, an activity of 0.02 fmol DMS cell ${ }^{-1} \mathrm{~min}^{-1}$ was measured at $\mathrm{pH} 8$.

Intra-strain variation of DMSP lyase activites was only small, Over more than a 1 yr investigation period, the general pattern of high-lyase strains (373 and 379) versus strains with low DMSP lyase activity remained unchanged

On the basis of the differing $\mathrm{pH}$ and $\mathrm{NaCl}$ requirements, we hypothesise that structural differences among the DMSP lyase isozymes could contribute to activity variation. Additionally, preliminary attempts to isolate DMSP lyase enzymes from Emiliania huxleyi indicated varying solubilities: after centrifugation $(105000 \times g)$ of crude extracts from 373 and 379 , recovery in the supernatant was 4 and $54 \%$ of total activity, 
respectively. Further purification steps with 379 indicated precipitation of DMSP lyase at 10 to $30 \%$ ammonium sulfate (hydrophobic protein), and incomplete binding to ion-exchange and hydrophobic-interaction chromatography columns. This partially purified DMSP lyase showed maximum activity at $35^{\circ} \mathrm{C}$, which was reduced to $84 \%$ at $30^{\circ} \mathrm{C}$ (Steinke pers. obs.).

Confirmation of structural differences will require protein purification and sequencing. The only DMSP lyases partially sequenced to date are from the marine bacteria Pseudomonas doudoroffii and Alcaligenes sp. strain M3A (deSouza \& Yoch 1996). However, we cannot dismiss the possibility that variable activities in $E$. huxleyi may be due to differing amounts of DMSP lyase per cell. Also, enzyme stability in the extracts may vary from strain to strain. Nevertheless, once the extracts were prepared and frozen at $-20^{\circ} \mathrm{C}$, DMSP lyase activity remained constant over many months.
Since bacterial DMSP lyases may be involved in DMS production, all experimental procedures were carried out with axenic cultures using sterile techniques. Nevertheless, sterility tests carried out may not be suitable to recognize intracellular bacteria. Therefore, the potential of contamination from such sources may be a cause of false interpretations that needs to be eliminated in future studies.

The presence of various DMSP lyase isozymes in Emiliania huxleyi is consistent with other recently published information concerning genetic diversity within this species (Young \& Westbroek 1991, Medlin et al. 1996) resulting in various morphotypes (van Bleijswijk et al. 1991) and altered cell physiology and growth characteristics (Brand 1982, van Bleijswijk et al. 1994). How DMSP lyase variation relates to other phenotypic or genotypic factors will require further characterisation of strains.

Table 3. Comparison of algal DMSP lyases in crude or cell-free extracts (purified enzymes noted; ND: not determined)

\begin{tabular}{|c|c|c|c|c|c|c|}
\hline \multirow{2}{*}{$\begin{array}{l}\text { Class } \\
\text { Species } \\
\text { Rhodophyceae }\end{array}$} & \multicolumn{2}{|c|}{$\begin{array}{l}\text { Maximum activity } \\
\text { perature }\left({ }^{\circ} \mathrm{C}\right) \text { pH }\end{array}$} & \multicolumn{2}{|c|}{$\begin{array}{l}\text { Cofactor } \\
\text { requirements }\end{array}$} & Location & Source \\
\hline & & & & & & \\
\hline Polysiphonia lanosa & $N^{a}$ & 5.1 & \multicolumn{2}{|c|}{$\begin{array}{l}\text { Reduced thiol } \\
\text { groups }^{b}\end{array}$} & $\begin{array}{l}\text { Bound to } \\
\text { subcellular fraction }\end{array}$ & Cantoni \& Anderson (1956) \\
\hline Polysiphonia paniculata ${ }^{\mathrm{c}}$ & $N^{d}$ & $\mathrm{ND}^{\mathrm{e}}$ & \multicolumn{2}{|c|}{$\mathrm{Mg}^{2+}, \mathrm{Ca}^{2+}$} & $\begin{array}{l}\text { Membrane bound } \\
\text { (vacuole?) }\end{array}$ & Nishiguchi \& Goff (1995) \\
\hline \multicolumn{7}{|l|}{ Chlorophyceae } \\
\hline Enteromorpha clathrata & 25 & $6.2-6.4$ & \multicolumn{2}{|c|}{ None $^{f}$} & Membrane bound & Steinke \& Kirst (1996) \\
\hline Ulva lactuca & ND & 8.5 & \multicolumn{2}{|c|}{ ND } & ND & Diaz \& Taylor (1994) \\
\hline Ulva curvatag & $\mathrm{ND}$ & 8 & \multicolumn{2}{|c|}{$75 \mathrm{mM} \mathrm{NaCl}$} & $\begin{array}{l}\text { Partially membrane } \\
\text { bound }\end{array}$ & de Souza et al. (1996) \\
\hline \multicolumn{7}{|l|}{ Haptophyceae } \\
\hline Phaeocystis sp. & $\geq 20^{\mathrm{h}}$ & $\geq 10.5$ & \multicolumn{2}{|c|}{$\mathrm{DTT} \geq 1 \mathrm{mM}$} & Outer cell surface & $\begin{array}{l}\text { Stefels \& Dijkhuizen (1996), } \\
\text { Stefels \& van Boekel (1993) }\end{array}$ \\
\hline $\begin{array}{l}\text { Emilania huxleyi } \\
\text { CCMP } 370\end{array}$ & ND & $\geq 8$ & \multicolumn{2}{|c|}{$\begin{array}{l}\mathrm{DTT} \geq 1 \mathrm{mM} \\
\mathrm{NaCl}=1 \mathrm{M}\end{array}$} & $\begin{array}{l}\text { Membrane bound, } \\
\text { inside cells }\end{array}$ & $\begin{array}{l}\text { Wolfe \& Steinke (1996), } \\
\text { this study }\end{array}$ \\
\hline CCMP 373 & ND & 6 & \multicolumn{2}{|c|}{$\mathrm{No} \mathrm{NaCl}$} & $\begin{array}{l}\text { Membrane bound, } \\
\text { inside cells }\end{array}$ & $\begin{array}{l}\text { Wolfe \& Steinke }(1996) \\
\text { this study }\end{array}$ \\
\hline CCMP 374 & ND & 5 & \multicolumn{2}{|c|}{$\mathrm{No} \mathrm{NaCl}$} & ND & This study \\
\hline CCMP 379 & $35^{i}$ & 6 & \multicolumn{2}{|c|}{$\mathrm{No} \mathrm{NaCl}$} & Membrane bound, $k$ & This study \\
\hline CCMP 1516 & & 5 & \multicolumn{2}{|c|}{$\mathrm{NaCl} \geq 2 \mathrm{M}$} & ND & This study \\
\hline Strain L & & 5 & \multicolumn{2}{|c|}{$\mathrm{NaCl} \approx 1 \mathrm{M}$} & ND & This study \\
\hline $\begin{array}{l}\text { Dinophyceae } \\
\text { Crypthecodinium } \\
\text { (Gyrodinium) cohnii }\end{array}$ & 27 & $6.0-6.5$ & $\geq 400 \mathrm{ml}$ & $\mathrm{NaCl}$ & $\mathrm{ND}^{l}$ & Kadota \& Ishida (1968) \\
\hline \multicolumn{4}{|c|}{ 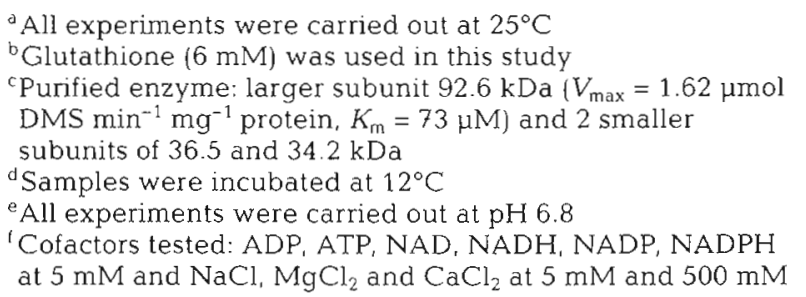 } & \multicolumn{3}{|c|}{$\begin{array}{l}\text { 9Purified enzyme: } 1 \text { soluble and } 3 \text { membrane-bound } \\
\text { monomers, all } 78 \mathrm{kDa}\left(\text { soluble monomer: } V_{\max }=86 \mu \mathrm{mol}\right. \\
\text { DMS min }{ }^{-1} \mathrm{mg}^{-1} \text { protein, } K_{\mathrm{m}}=520 \mu \mathrm{M} \text { ) } \\
\text { hIn whole cells } \\
\text { I Steinke pers. obs. } \\
{ }^{\mathrm{k}} \text { Enzyme precipitated at } 10 \text { to } 30 \% \text { ammonium sulfate } \\
\text { (highly hydrophobic) } \\
\text { 'Enzyme precipitated at } 25 \text { to } 50 \% \text { ammonium sulfate } \\
\text { (hydrophobic) }\end{array}$} \\
\hline
\end{tabular}




\section{Comparison with DMSP lyases from other algae}

Table 3 summarises the DMSP lyase behaviour in crude Emiliania huxleyi extracts with other algal DMSP lyase enzymes which have been characterised or isolated.

Our findings characterise the DMSP lyases from strains L, 370 and 1516 as halophilic enzymes, comparable with other halotolerant and halophilic enzymes in marine organisms (Bylund et al. 1991, Vegavillasante et al. 1993). With the exception of the dinoflagellate Crypthecodinium (Gyrodinium) cohnii, these Emiliania huxleyi strains are the only others to have DMSP lyases with a significant salt requirement. The DMSP lyase of Polysiphonia paniculata required 20 to $40 \mu \mathrm{M}$ $\mathrm{Mg}^{2+}$ or $\mathrm{Ca}^{2+}$ ions for optimal activity with little effect above this concentration (Nishiguchi \& Goff 1995), and Ulva curvata required $75 \mathrm{mM} \mathrm{NaCl}$ to stimulate DMSP cleavage, but activity was reduced by $40 \%$ at $600 \mathrm{mM}$ $\mathrm{NaCl}$ (de Souza et al. 1996)

Of the few algal DMSP lyases examined to date many require acidic $\mathrm{pH}$ for optimal activity. A preference for acidic $\mathrm{pH}$ was found in the macroalgae Polysiphonia lanosa (Cantoni \& Anderson 1956), Enteromorpha clathrata (Steinke \& Kirst 1996) and the heterotrophic dinoflagellate Crypthecodinium cohnii (Kadota \& Ishida 1968). All Emiliania huxleyi strains except strain 370 showed similar response. However, there are also DMSP lyases which are active under alkaline conditions, including those from Ulva lactuca (Diaz \& Taylor 1994) and U. curvata (de Souza et al. 1996), and the haptophyte Phaeocystis sp. (Stefels \& Dijkhuizen 1996). The latter showed increasing DMSP lyase activity with increasing $\mathrm{pH}$ (to a maximum value at $\mathrm{pH} 10.5$, the highest $\mathrm{pH}$ tested in the study) similar to the pattern showed for strain 370 (Fig. 3B).

The widespread occurrence of the DMSP lyase enzyme, and the variations in its behaviour, suggest a broad family of DMSP lyase isozymes, possibly with several fundamental forms. Bacterial DMSP lyases are a good example, since they show considerable variation (Yoch et al. 1997), have been more fully characterised and may offer some insight into possible algal DMSP lyase location and function. The cytoplasmic DMSP lyase from Pseudomonas doudoroffii (de Souza \& Yoch 1996) required $600 \mathrm{mM}$ salt for optimal activity and showed an acidic $\mathrm{pH}$ optimum, while the periplasmic or cell-surface DMSP lyase from Alcaligenes strain M3A (de Souza \& Yoch 1995b) showed no salt requirement and an alkaline $\mathrm{pH}$ optimum. The DMSP lyase from the haptophyte Phaeocystis sp. is also thought to be a cell-surface enzyme, and also shows no salt requirement and high pH optimum (Stefels \& Dijkhuizen 1996). It is therefore feasible that the enzymes in Emiliania huxleyi differ not only in behaviour, but in cellular location. Two studies have found evidence for both membrane-bound and soluble DMSP lyase activity within an organism (Nishiguchi \& Goff 1995, de Souza et al. 1996). Hence, it cannot be ruled out that DMSP lyase activities reported in this study result from a mixture of various isozymes present in $1 E$. huxleyi strain.

There is also evidence for variation in DMSP lyase function at the genus level among macroalgae. In a study investigating 21 algal strains (Steinke et al. 1996), the closely related macroalgal species Enteromorpha intestinalis, E. clathrata and E. compressa showed high DMSP lyase activities of 10 to $100 \mathrm{nmol}$ DMS $\mathrm{mg}^{-1}$ cell protein $\mathrm{min}^{-1}$ and intracellular DMSP concentrations of 25 to $90 \mathrm{mmol}$ DMSP $\mathrm{kg}^{-1}$ fresh weight. Activities in 2 strains of E. bulbosa were about 1000 -fold lower, averaging $0.01 \mathrm{nmol}$ DMS $\mathrm{mg}^{-1}$ cell protein $\mathrm{min}^{-1}$ despite a similar intracellular DMSP concentration of 20 to $50 \mathrm{mmol}$ DMSP $\mathrm{kg}^{-1}$ fresh weight. Although the enzyme assay used by Steinke et al. (1996) was optimised to test for DMSP lyase in $E$. clathrata, the results indicated the presence of DMSP lyase isozymes with various total activities and possibly also differences in requirements for optimal activity. The diversity seen here within Emiliania huxleyi suggests that DMSP lyase isozyme variants may also be common in microalgae.

\section{Implications for DMSP lyase activity and DMS production in vivo}

During exponential and stationary growth of Emiliania huxleyi, we found only little production of DMS by axenic cultures (Wolfe \& Steinke 1996), despite consistent in vitro DMSP lyase activity per cell over the growth period. This implies that in all strains this reaction is strongly repressed. We previously suggested that physical separation of the DMSP lyase and DMSP might be a mechanism, based on the activation of this reaction following cell lysis (Wolfe \& Steinke 1996). However, the reaction might also be highly regulated in vivo by the different $\mathrm{NaCl}$ and $\mathrm{pH}$ requirements in situ, depending on the cellular location of the enzyme. Fluorescent dye measurements of internal $\mathrm{pH}$ in E. huxleyi suggest cytoplasmic values around 7. with chloroplast pH as high as 8 (Dixon et al. 1989). Since alkaline $\mathrm{pH}$ reduces DMSP lyase activity in most strains except for 370 , this might explain why DMS production is so low in vivo. Interestingly, we previously found that strain 370 produced relatively high in vivo DMS compared to strain 373, despite the much lower activity of its enzyme in crude extracts (Wolfe \& Steinke 1996). 


\section{Possible functions of DMSP cleavage reaction}

The role of the DMSP cleaving reaction in phytoplankton or macroalgal physiology is still unknown. DMSP is well recognised to function as a compatible solute, so the degradation of internal osmotica following external salt stress is the assumed natural function of this reaction. However, there is little if any evidence that cellular DMSP is involved in short-term osmotic adjustment but may change with long-term stress and especially under high salinities (Dickson \& Kirst 1986 Kirst 1990). The role of the cleavage products has not been critically examined. DMS, a small, polar molecule, would almost certainly diffuse rapidly from cells the size of Emiliania huxleyi. Acrylate and a proton would most likely remain. The metabolism of acrylate by algae has not been studied, and it is not clear what function it might serve.

Recently, we suggested that this reaction, which does not appear to proceed under in vivo growth conditions, might be stimulated by cell lysis, as, for example, following grazing by protozoan herbivores. We found that such grazing resulted in increased production of DMS and the amount of DMS produced was consistent with relative in vitro DMSP lyase activity in the investigated strain (Wolfe \& Steinke 1996). Also, high lyase strains such as 379 were grazed at lower rates than low lyase strains (Wolfe et al. 1997). Based on the feeding preferences of marine protozoan herbivores, Wolfe et al. (1997) concluded that this reaction may potentially be involved in a grazing-activated chemical defence mechanism by producing concentrated acrylate.

The protistan digestion process is initiated by fusion of acidosomes with the food vacuole, resulting in a

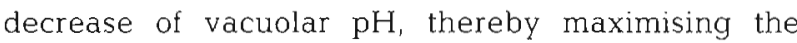
activity of hydrolytic enzymes (Hausmann \& Hülsmann 1996). Our data suggest that the DMSP Iyase enzyme could maintain activity within the protozoan food vacuole following ingestion. In the ciliate Paramecium, the $\mathrm{pH}$ of the food vacuole is decreased to $\mathrm{pH} 3$ only 4 to 8 min after ingestion (Fok et al. 1982), but the process may take significantly longer in other predators (Dodge \& Crawford 1974, Öpik \& Flynn 1989). Additionally, it is a common occurrence for small prey organisms to remain active for a limited time after ingestion (Grula \& Bovee 1977). If not all prey is immediately digested and still metabolically active after ingestion by a protist, the temporal gradient of $\mathrm{pH}$ and ionic conditions experienced by the ingested prey cell may allow optimal activity of Emiliania huxleyi DMSP lyases. Even a short period of high lyase activity during the digestion process may convert most of the algal DMSP to DMS and acrylate: Wolfe \& Steinke (1996) calculated cleavage of roughly $60 \%$ of the prey DMSP during only 3 to 5 min after ingestion of strain 373 by Oxyrrhis marina, resulting in average DMS, and hence acrylate production of $65 \mathrm{mM}$.

\section{Conclusions}

In Emiliania huxleyi, DMSP lyase isozymes with various requirements for optimal activity resulted in strain-specific DMS production rates in vitro. The specific rates were not constant but varied during an investigation period of several months. Nevertheless, the general pattern of high-and low-activity strains remained true over more than a 1 yr cultivation period. There were pronounced differences among DMSP lyase characteristics from different strains. We suggest that the strains with high activity have structurally different DMSP lyases - which then may result in higher DMS production rates-rather than simply having higher DMSP lyase titers per cell. However, only amino acid sequencing of purified DMSP lyase would ultimately explain structural differences.

Assuming that DMSP lyases are still active after loss of cell integrity, the enzyme requirements demonstrated here may be important clues to the fate of dissolved DMSP in seawater. Algal DMSP lyases probably compete with bacterial pathways for DMSP utilisation but we do not know for how long free algal DMSP lyases remain active.

The cellular location of DMSP and DMSP lyases in Emiliania huxleyi needs further investigation. There is evidence that DMSP lyases in E. huxleyi are membrane-bound (Wolfe \& Steinke 1996, Steinke pers. obs.) but what organelles are involved in enzyme-substrate segregation is still unknown. Finally, the activation of DMS production after cell ingestion by herbivorous protists (Wolfe et al. 1997) and the fate of acrylate, which is produced during this process, is an attractive task for future research. Acrylate production may affect competition and species succession in microbial communities, whereas knowledge on DMS production pathways is essential for our understanding of the oceanic and atmospheric sulfur cycle and its implications for global climate.

Acknowledgements. The authors thank Gill Malin and 3 anonymous reviewers for their valuable comments. We also thank Steffi Kurk and Ina Plettner for assistance with the Emiliania huxleyi growth studies. Brian Palenik graciously provided the E. huxleyi cultures CCMP 1516 and strain L. and Heide Grafe, Oliver Nixdorf and Mark de Souza are acknowledged for many helpful suggestions. This research was supported by the European Union (EV5V-CT93-0326), the Deutsche Forschungsgemeinschaft, and the National Aeronautical and Space Administration (NASA; NAGW3737). 


\section{LITERATURE CITED}

Andreae MO, Jaeschke WA (1992) Exchange of sulphur between biosphere and atmosphere over temperate and tropical regions. In: Howarth RE, Stewart JWB, Ivanov MV (eds) Sulphur cycling on the continents - wetlands, terrestrial ecosystems and associated water bodies. Wiley \& Sons, Chichester, p 27--61

Andreae MO, Ferek RJ, Bermond F, Byrd KP, Engstrom RT, Hardin S, Houmere PD, LeMarrec F, Raemdonck H, Chatfield RB (1985) Dimethyl sulfide in the marine atmosphere. J Geophys Res 90:12891-12900

Bacic MK, Yoch DC (1998) In vivo characterization of dimethylsulfoniopropionate lyase in the fungus Fusarium lateritium. Appl Environ Microbiol 64:106-111

Barker GLA, Green JC, Hayes PK, Medlin LK (1994) Preliminary results using the RAPD analysis to screeen bloom populations of Emiliania huxleyi (Haptophyta). Sarsia 79: 301-306

Bates TS, Charlson RJ, Gammon RH (1987) Evidence for the climatic role of marine biogenic sulphur. Nature 329 : $319-321$

Beam CA, Himes M (1987) Electrophoretic characterization of members of the Crypthecodinium cohnii (Dinophyceae) species complex. J Protozool 34:204-217

Blunden G, Smith BE, Irons MW, Yang MH, Roch OG, Patel AV (1992) Betaines and tertiary sulphonium compounds from 62 species of marine algae. Biochem Syst Ecol 20: $373-388$

Brand LE (1982) Genetic variability and spatial pattern of genetic differentiation in the reproductive rates of the marine coccolithophores Emilianja huxleyi and Gephyrocapsa oceanica. Limnol Oceanogr 27:236-245

Bratbak G, Levasseur M. Michaud S, Cantin G, Fernandez E Heimdal BR, Heldal M (1995) Viral activity in relation to Emiliania huxleyi blooms: a mechanism of DMSP release? Mar Ecol Prog Ser 128:133-142

Brussard CPD, Riegman R, Noordeloos AAM, Cadée GC, Witte H, Kop AJ, Nieuwland G, van Duyl FC, Bak RPM (1995) Effects of grazing, sedimentation and phytoplankton cell lysis on the structure of a coastal pelagic food web. Mar Ecol Prog Ser 123:259-271

Bylund JE, Dyer JK, Thompson TL, Martin EL (1991) Alanine dehydrogenase-activity of the extensively halotolerant eubacterium Halomonas elongata. Microbios 66:45-53

Cantoni GL, Anderson DG (1956) Enzymatic cleavage of dimethylpropiothetin by Polysiphonia lanosa. J Biol Chem 22:171-177

Challenger $F(1959)$ Aspects of the organic chemistry of sulphur. Butterworths Scientific Publications, London

Charlson RJ, Lovelock JE, Andreae MO, Warren SG (1987) Oceanic phytoplankton, atmospheric sulphur, cloud albedo and climate. Nature 326:655-661

Conte MH, Thompson A, Eglinton G, Green JC (1995) Lipid biomarker diversity in the coccolithophorid Emiliania huxleyi (Prymnesiophyceae) and the related Gephyrocapsa oceanica. J Phycol 31:272-282

Dacey JWH, Blough NV (1987) Hydroxide decomposition of dimethylsulfoniopropionate to form dimethylsulfide. Geophys Res Lett 14:1246-1249

Dacey JWH, Wakeham SG (1986) Oceanic dimethylsulfide: production during zooplankton grazing on phytoplankton. Science 233:1314-1316

de Souza MP, Yoch DC (1995a) Comparative physiology of dimethyl sulfide production by dimethylsulfoniopropionate lyase in Pseudomonas doudoroffii and Alcaligenes sp. strain M3A. Appl Environ Microbiol 61:3986-3991 de Souza MP, Yoch DC (1995b) Purification and characterization of dimethylsulfoniopropionate lyase from an Alcallgenes-like dimethyl sulfide-producing marine isolate Aspl Environ Microbiol 61:21-26

de Souza MP, Yoch DC (1996) N-Terminal amino acid sequences and comparison of DMSP lyases from Pseudomonas doudoroffii and Alcaligenes strain M3A. In: Kiene RP, Visscher PT, Keller MD, Kirst GO (eds) Biological and environmental chemistry of DMSP and related sulfonium compounds. Plenum Press, New York, p 293-304

de Souza MP, Chen YP, Yoch DC (1996) Dimethylsulfoniopropionate lyase from the marine macroalga Ulva curvata: purification and characterization of the enzyme. Planta 199:433-438

Diaz MR, Taylor BF (1994) Comparison of dimethylsulfoniopropionate lyase activity in a prokaryote and a eukaryote. Ann Gen Meet Am Soc Microbiol, Abstract N18:319

Dickson DMJ, Kirst GO (1986) The role of b-dimethylsulphoniopropionate, glycine betaine and homarine in the osmoacclimation of Platymonas subcordiformis. Planta 167: $536-543$

Dixon GK, Brownlee C, Merrett MJ (1989) Measurement of internal $\mathrm{pH}$ in the coccolithophore Emiliania huxleyi using 2:7'-bis-(2-carboxyethy) -5 (and-6) carboxyfluoresceinacetoxymethylester and digital imaging micrsocopy. Planta $178: 443-449$

Dodge JD, Crawford RM (1974) Fine structure of the dinoflagellate Oxyrrhis marina. III-Phagotrophy. Protistologica 10:239-244

Fok AK, Lee Y, Allen RD (1982) The correlation of digestive vacuole $\mathrm{pH}$ and size with the digestive cycle in Paramecium caudatum. J Protozool 29:409-414

Gallagher JC (1982) Physiological variation and electrophoretic banding patterns of genetically different seasonal populations of Skeletonema costatum (Bacillariophyceae). J Phycol 18:148-162

Grula $M$, Bovee EC (1977) Ingestion and subsequent loss of a rotifer by Stentor coeruleus. Trans Am Microsc Soc 96 $538-539$

Guillard RRL (1975) Culture of phytoplankton for feeding marine invertebrates. In: Smith WL, Chanley $\mathrm{MH}$ (eds) Culture of marine invertebrate animals. Plenum Press New York, p 29-60

Hausmann K, Hülsmann N (1996) Protozoology. Thieme, Stuttgart

Hobbie JE, Daley RJ, Jasper S (1977) Use of nuclepore filters for counting bacteria by fluorescence microscopy. Appl Environ Microbiol 33:1225-1228

Kadota H, Ishida Y (1968) Effect of salts on enzymatical production of dimethyl sulfide from Gyrodinium cohnii. Bull Jap Soc Sci Fish 34:512-518

Keller MD, Bellows WK, Guillard RRL (1989) Dimethylsulfide production in marine phytoplankton. In: Saltzman ES, Cooper WJ (eds) Biogenic sulfur in the environment. American Chemical Society, Washington, DC, p 167-182

Kiene RP, Visscher PT, Keller MD, Kirst GO (1996) Biological and environmental chemistry of DMSP and related sulfonium compounds. Plenum Press, New York

Kirst GO (1990) Salinity tolerance of eukaryotic marine algae. Annu Rev Plant Physiol Plant Mol Biol 41:21-53

Ledyard KM, Dacey JWH (1994) Dimethylsulfide production from dimethylsulfoniopropionate by a marine bacterium Mar Ecol Prog Ser 110:95-103

Levasseur M, Michaud S, Egge J, Cantin G, Nejstgaard JC, Sanders R, Fernandez E, Solberg PT, Heimdal B, Gossel.in $M$ (1996) Production of DMSP and DMS during a mesocosm study of an Emiliania huxleyi bloom: influence of 
bacteria and Calanus finmarchicus grazing. Mar Biol 126 $609-618$

Liss PS, Hatton AD, Malin G, Nightingale PD, Turner SM (1997) Marine sulphur emissions. Phil Trans R Soc Lond B $352: 159-168$

Malin G, Kirst GO (1997) Algal production of dimethyl sulfide and its atmospheric role. I Phycol 33:889-896

Malin G, Turner SM, Liss PS (1992) Sulfur: the plankton/ climate connection. J Phycol 28:590-597

Malin G, Turner S, Liss P, Holligan P, Harbour D (1993) Dimethylsulphide and dimethylsulphoniopropionate in the northeast Atlantic during the summer coccolithophore bloom. Deep-Sea Res Part A Oceanogr Res Pap 40 $1487-1508$

Malin G, Wilson WH, Bratbak G, Liss PS, Mann NH (1998) Elevated production of dimethylsulfide resulting from viral infection of cultures of Phaeocystis pouchetii. Limnol Oceanogr 43:1389-1393

Matrai PA, Keller MD (1993) Dimethylsulfide in a large-scale coccolithophore bloom in the Gulf of Maine. Cont Shelf Res 13:831-843

Medlin LK, Barker GLA, Campbell L, Green JC, Hayes PK, Marie D, Wrieden S, Vaulot D (1996) Genetic characterisation of Emiliania huxleyi (Haptophytà). J Mar Sys 9: $13-31$

Nishiguchi MK, Goff LJ (1995) Isolation, purification, and characterization of DMSP lyase (dimethylpropiothetin dethiomethylase (4.4.1.3)) from the red alga Polysiphonia paniculata. J Phycol 31:567-574

Öpik H, Flynn KJ (1989) The digestive process of the dinoflagellate, Oxyrrhis marina Dujardin, feeding on the chlorophyte, Dunaliella primolecta Butcher: a combined study of ultrastructure and free amino acids. New Phytol 113: $143-151$

Plane JM (1989) Gas phase atmospheric oxidation of biogenic sulfur compounds. In: Saltzman ES, Cooper WJ (eds) Biogenic sulfur in the environment. American Chemical Society, Washington, DC

Pond DW, Harris RP (1996) The lipid composition of the coccolithophore Emiliania huxleyi and its possible ecophysiological significance. J Mar Biol Assoc UK 76:579-594

Reed RH (1983) Measurement and osmotic significance of b-dimethylsulphoniopropionate in marine macroalgae. Mar Biol Lett 4:173-181

Riegman R, Noordeloos AAM, Cadée GC (1992) Phaeocystis blooms and eutrophication of the continental coastal zones of the North Sea. Mar Biol 112:479-484

Sherr EB, Caron DA, Sherr BF (1993) Staining of heterotrophic protists for visualization via epifluorescence microscopy. In: Kemp PF, Sherr BF, Sherr EB, Cole JJ (eds) Handbook of methods in aquatic microbial ecology. Lewis Publishers, Boca Raton, p 213-227

Sieburth JM (1960) Acrylic acid, an 'antibiotic' principle

Editorial responsibility: Otto Kinne (Editor),

Oldendorf/Luhe, Germany in Phaeocystis blooms in Antarctic waters. Science 132 676-677

Stable JE, Gallagher JC, Wurtzel ET (1990) Molecular analysis of intraspecific variation in the marine diatom Skeletonema costatum. Biochem Syst Ecol 18:5-9

Stefels J, Dijkhuizen L (1996) Characteristics of DMSP-lyase in Phaeocystis sp (Prymnesiophyceae). Mar Ecol Prog Ser 131:307-313

Stefels J, van Boekel WHM (1993) Production of DMS from dissolved DMSP in axenic cultures of the marine phytoplankton species Phaeocystis sp. Mar Ecol Prog Ser 97: $11-18$

Steinke M, Kirst GO (1996) Enzymatic cleavage of dimethylsulfoniopropionate (DMSP) in cell-free extracts of the marine macroalga Enteromorpha clathrata (Roth) Grev. (Ulvales, Chlorophyta). J Exp Mar Biol Ecol 201:73-85

Steinke M, Daniel C, Kirst GO (1996) DMSP Lyase in marine macro- and microalgae: intraspecific differences in cleavage activity. In: Kiene RP, Visscher PT, Keller MD, Kirst GO (eds) Biological and environmental chemistry of DMSP and related sulfonium compounds. Plenum Press, New York, p 317-324

van Bleijswijk J, van der Wal P, Kempers RS, Veldhuis $M$ (1991) Distribution of two types of Emiliania huxleyi (Prymnesiophyceae) in the northeast Atlantic region determined by immunofluorescence and coccolith morphology. J Phycol 27:566-570

van Bleijswijk JDL, Kempers ES, Veldhuis MJW (1994) Cell and growth characteristics of types $\mathrm{A}$ and $\mathrm{B}$ of Emiliania huxleyi (Prymnesiophyceae) as determined by flow cytometry and chemical analysis. J Phycol 30:230-241

van der Maarel MJEC, van Bergeijk $S$, van Werkhoven $A F$, Laverman AM, Meijer WG, Stam WT, Hansen TA (1996) Cleavage of dimethylsulfoniopropionate and reduction of acrylate by Desulfovibrio acrylus sp. nov. Arch Microbiol 166:109-115

Vegavillasante F, Nolasco H, Civera R (1993) The digestive enzymes of the Pacific brown shrimp Penaeus californiensis. 1. Properties of amylase activity in the digestive tract. Comp Biochem Physiol B 106:547-550

Wolfe GV, Steinke M (1996) Grazing-activated production of dimethyl sulfide (DMS) by two clones of Emiliania huxleyi. Limnol Oceanogr 41:1151-1160

Wolfe GV, Steinke M, Kirst GO (1997) Grazing-activated chemical defence in a unicellular marine alga. Nature 387:894-897

Yoch DC, Ansede JH, Rabinowitz KS (1997) Evidence for intracellular and extracellular dimethylsulfoniopropionate (DMSP) lyases and DMSP uptake sites in two species of marine bacteria. Appl Environ Microbiol 63:3182-3188

Young JR, Westbroek P (1991) Genotypic variation in the coccolithophorid species Emiliania huxleyi. Mar Micropaleontol 18:5-23

Submitted: March 9, 1998; Accepted: September 9, 1998 Proofs received from author(s): December 7, 1998 